\title{
The Influence of Risk Management on Organizational Efficiency: A Study of Access Bank Ghana Limited
}

\author{
Lady Nadia Frempong ${ }^{1^{*}} \quad$ Obed Tettey Nartey ${ }^{2^{*}} \quad$ Bright Asiamah Korankye ${ }^{2^{*}}$ \\ 1. College of Management, Sichuan Agricultural University, Chengdu 611130, China \\ 2. Big Data Research Center, School of Computer science and Engineering, University of Electronics Science \\ and Technology of China \\ 2. School of Economics and Management, University of Electronics Science and Technology of China
}

The research is self-financed

\begin{abstract}
The study investigates the influence of risk management on organizational efficiency. The research was done in Ghana, in particular Access Bank Ghana Ltd (UPSA Branch) as the case study. The objectives of the study were aimed at understanding of risk management, knowing the potency of risk identification, risk assessment and analysis, risk monitoring and controlling with it impact on organizational efficiency. Simple random sampling was used to select fifteen respondents. The research instruments majorly used included a set of questionnaires for respondents. The findings of the study multiple linear regression show that risk monitoring as an element of risk management was a positive relationship of $0.555(55.5 \%)$ and significant predictor with to organizational efficiency of $(\beta=0.733, t(15)=3.398, p<0.050)$. The ANOVA test for the fitness of the model was also positive and significant and the study model was accepted. Correlation matrix was estimated using Pearson correlation to check the positive and strong association between risk identification, understanding of risk and risk monitoring. The findings established strong positive relationship between them. The study concluded that the bank assesses its risks by using quantitative and qualitative methods. The study recommended that a method for identifying, assessing, analyzing and measuring the key business risks in Access Bank Ghana Ltd be make available to all employees.
\end{abstract}

Keywords: Risk management, Organizational efficiency

DOI: $10.7176 /$ RJFA/10-10-15

Publication date:May $31^{\text {st }} 2019$

\section{Introduction}

Risk is inevitable and inborn in each and every economic activity. Hence the importance of risk management in any organization cannot be overemphasized. This is very important for every industry especially the banking industry. Risk simply refers to the chance that an investments' actual return will be different than expected. It includes the possibility of losing some or all of the original investments. Management is meeting an organization's goals with limited resources. It involves decision making about what goals to pursue and how to attain them (Marko, 2007). However, without taking risk, the growth of businesses is just like nightmares (Asim et al., 2012). According to Brain (2001) risk occurs when outcome is uncertain. Risk exists as a part of an environment in which various organizations operate (Shafiq \& Nasr, 2010) so each and every business has to face risk.

Risk management therefore is the total process of identifying, controlling and minimizing the impact of uncertain events. Risk management refers to a process of identifying loss exposures faced by an organization and selecting the most appropriate techniques for treating these particular exposures effectively (Drennan \& Rejda, 2003). Wenk, (2005) also pointed that, risk management is the identification, assessment, and prioritization of risks followed by coordinated and economical application of resources to minimize, monitor, and control the probability and/or impact of unfortunate events or to maximize the realization of opportunities. Dorfman (2007) however holds that, ensuring that an organization makes cost effective use of risk management, first involves creating an approach built up of well-defined risk management practices and then embedding them. These risk management practices include financial risks management practices, operational risk management practices, governance risk management practices, and strategic risk management practices.

The banking system assumes an important role in the financial intermediation process of every economy making its effectiveness and efficiency a vital necessity towards ensuring stability and development (Halling \& Hayden, 2006). Banks like all businesses face various types of risk which arise due to the nature of their activities. Financial institutions in general are however exposed to variety of risks among them; interest rate risk, foreign exchange risk, political risk, market risk, liquidity risk, operational risk and credit risk (Cooperman, Gardener and Mills, 2000). However, the major aim of banks is to maximize profit by managing risk and by providing various financial services (Alimshan, 2011). According to Diamond and Rajan (2001) banks participate in important economic activities and have primary concerns to address so as to ensure their survival and profitability. Hence financial institutions cannot do without taking a risk in their operations. They share risk with both lenders and borrowers (Ashfaq, 2009).

Risk management is an essential component of strategic management of an organization. It is an ongoing 
process of risk assessment through different tools and methods which identify all possible risks, determine which risks are critical to solve as soon as possible and then execute strategies to deal with these risks (Tariqullah \& Habib, 2001). An efficient and effective risk management is the need of each and every organization and is one of the key responsibilities of bank. However effective risk management boosts the performance of an organization. The past financial crises uncovered shortcomings in the performance and risk management practices with many banks taking on excessive risk with too little regard for long run performance (Sitanta, 2011). Banks can grab opportunities with greater confidence only with an integrated approach of managing risk and performance.

Risk management is an activity within project management that is gaining importance because businesses are moving towards globalization and because of the increasing competition (Ahmed et al., 2007). The risk management process consists of a series of steps, which are establishing the context, identifying, analyzing, assessing, treating, monitoring and communicating risks, which allow continuous improvement of decision making. As Ferreira (2006) has defined risk management, it involves managing to achieve a proper balance between realizing opportunities for gains while minimizing losses. As this definition implies, risk management is an integral part of a good management practice and an essential element of excellent corporate governance (Ferreira, 2006).

Risk management is a repetitive process that constitutes steps that when taken consequently; it facilitates improved decision-making and performance. In any case, banks still need to encourage trade through the provision of payment and settlement frameworks, ensuring the productive investment of capital and the profitability of other differed capacities (Jenkison, 2008). Owing to this fact, banks will definitely be open to numerous risks which incorporate liquidity risk, credit risk, foreign exchange risk, market risk, interest rate risk among others. However, the best approach ought to be utilized to ensure that banks keep on enjoying their profitability and also ensures that, services offered by them are relatedly connected with the requirements of their clients. This will lead to an increase in revenue, customer's loyalty and very long term profitability. Based on the facts above, Ghana has seen a strained competition among her banks for client deposits which has been portrayed by consistent advertisement in both the print and electronic media, attractive promotions and the employment of people who sale to different clients on regular basis the different banking products offered by them in their quest to maximize client deposits (Gyamfi, 2012). Admitting to this fact implies that, risk if not well managed could lead to collapse for most organizations especially those whose core business deals with day to day handling of risk. Risk management should, therefore, be at the core of an organization's operations by integrating risk management practices into processes, systems and culture of the entire organization. In the view of this, it is vital to comprehend the influence of risk management on organizational efficiency focusing on the banking industries.

The general purpose of the study is to examine whether the risk management influences on the organizational efficiency of Access Bank Ghana Limited. The study focused on the following specific objectives; To assess the understanding of risk management within the staff of Access bank Ghana Ltd., To investigate the potency of risk identification, risk monitoring and controlling within Access bank Ghana Ltd. and to examine the influence of risk management on organizational efficiency within the Access Bank Ghana Ltd.

The study formulated the following research questions to assist the study ascertain the objectives of the study; What is the level of understanding of risk management within the staff of Access bank Ghana Ltd?, What is the level of risk identification, risk monitoring and controlling of different risks in Access bank Ghana Ltd? And What is the level of the impact of risk management on organizational efficiency in Access Bank Ghana Ltd?

This study would be very relevant since it will contribute to existing knowledge on the study in question. The finding of this study will form an empirical background for all researchers who will be interested in investigating on the effect of risk management practices on organizational efficiency. Especially in the banking industries since the study was focused on the banking sector. Finally, the findings of the study would serve as the basis for possible recommendations and provides policy measures to the various stakeholders to tackle the influence of risk management in order to enhance the quality of Banks' risk assets.

\section{Literature Review}

Access Bank launched its operations in Ghana on August 19, 2009, as one of the most capitalized commercial banks in the industry. The entry of Access Bank into the Ghanaian economy signaled the beginning of a new era in the annals of banking because of its acknowledged reputation for innovation and service excellence across Africa and beyond. Since inception, the Bank has provided universal banking services to nearly the entire population in Ghana and has acted as a catalyst for growth and socio-economic development. The Bank's experience in Trade Finance, Treasury and Relationship management services has also positioned it as the preferred partner for global businesses and international financial institutions seeking to do business in Ghana. As a dependable partner, Access Bank has continued to partner the Government, local businesses and communities to deliver world-class banking services and provide financial support in key areas of the economy.

\subsection{Tools for Risk Management}

There are a lot of factors or tools for risk management but for the purpose of the study few were considered such 
as performance, network, technology service and products innovation and business segment

\subsubsection{Performance}

Access Bank's performance in the Ghanaian economy over the past 8 years mirrors the leadership position of its parent company, Access Bank Plc, which is ranked amongst the top 20 banks in Africa by assets and capital. The Bank is today reputed as one of the fastest growing banks in Ghana, having demonstrated consistent year-on-year growth across key financial indicators. Its financial performance, governance and risk management policies have helped to build stakeholder confidence in the Bank's operations. In 2016, the Bank was listed on the Ghana Stock Exchange (GSE) as the $11^{\text {th }}$ Bank and the $41^{\text {st }}$ company after successfully completing its Initial Public Offer. This feat also occasioned a name change from Access Bank (Ghana) Limited to Access Bank Ghana Plc and positioned the Bank as the first Ghanaian bank of Nigerian origin to list on the GSE. Access Bank Ghana Plc has also been a beneficiary of a $\$ 40$ million credit facility from the French Development Bank, PROPARCO and its Dutch counterpart Netherlands Development Finance Company (FMO) as well as $€ 15$ million from the European Investment Bank to support its lending activities to the private sector in the Ghanaian economy. As at December 31, 2016, the Bank's stated capital was over GHS 144million with a shareholders' fund in excess of GHS429 million.

\subsubsection{Network}

As a subsidiary of Access Bank Plc, the Bank leverages on the Group's robust technology driven platform, which has been time-tested and acclaimed as one of the best in the world. The Access Bank Group's international network spans sub-Saharan Africa's three monetary zones (Congo DRC, Gambia, Ghana, Nigeria, Rwanda, Sierra Leone, and Zambia), China and India in the Far East, Dubai and Lebanon in the Middle East and the United Kingdom. The Bank's well-established global network enables it to provide customers and other stakeholders with valuable local knowledge and contacts, and the distinct advantage of a truly international Bank. Currently, Access Bank operates from 50 business offices located in major cities and commercial centers across the country.

\subsubsection{Technology, Services and Product Innovation}

Access Bank is able to develop competitively priced and convenient banking solutions, including mobile \& internet banking, SMS \& Email alerts, E-statement, VISA, MasterCard and Verve services as well as Payroll management solutions. The Bank's comprehensive range of banking services is value driven and able to satisfy multiple stakeholders simultaneously. It boasts of specialized products and services tailored to meet the varying needs of large corporate organizations, including their subsidiaries, partners, suppliers, distributors, employees and individual customers.

\subsubsection{Business Segments}

It is the desire of Access Bank Ghana limited to satisfy various segments of the Ghanaian economy. This has made them to have a well-defined informed business model that would provide a range of products and services to meet the needs of people in each segment of the market. Their business module covers: Business Banking, Corporate Banking, Women Banking, Private Banking, Commercial Banking, Personal Banking and Investment Banking.

\subsection{Theory of Risk Management}

\subsubsection{Agency Theory}

Agency theory explains how best to establish associations in which one party(principal) determines the work while another party (agent) does the work. In agency relationship, one party delegates work to another party (Jensen and Meckling1976; Ross, 1973; Eisenhardt,1989). It is a useful framework for designing governing, monitoring and controlling in an organization. This theory helps management to assess the company capabilities and short falls and uses the result to demonstrates how the theory has been adopted by different companies. This agency theory helps in risk monitoring and identification as they were the variables used in the analysis. According to Smith and Stulz (1985) in the field of corporate risk management agency problems have been made known to impact managerial behaviors towards risk taking and evading.

\subsection{Empirical Literature Review}

\subsubsection{A Similar Study in the Banking Sector}

Al-Tamimi and Al-Mazrooei (2007) conducted research to compare the risk management practices and techniques in dealing with different types of risk in national and foreign banks of UAE. The aim of research was to identify the risk management practices and procedures in UAE banks. The result showed that these banks are more capable for managing risk and also found that UAE national and foreign banks are unlike to each other in risk assessment, its analysis, examine and controlling.

Afsheen et al. (2010) have researched on Risk Management Practices Followed by the Commercial Banks in Pakistan. This research paper aims to examine the awareness about risk management within the banking sector of Pakistan. Both Primary and secondary data collection sources were used. Primary data was gathered from 15 commercial bank's risk management departments. The secondary data was collected from performance review of the banking system report of the period of 9 years from 2000 to 2008. Findings of this empirical study have shown 
that there is a considerable dissimilarity in the use of risk management aspects among the commercial banks in both public and private sectors. Also, the financial reliability indicators differ in significance for each type of commercial bank. Although staff of commercial banks has a general understanding about risk and its management, still there is a need for commercial banks to provide training to staff in risk management tailored according to their needs.

\subsubsection{A Similar Study in the Health Sector}

This study conducted by Ministry of health- New Zealand (1998) was a guideline written to provide basic framework to help mental health clinicians to assess and manage clinical risk issues. It considers all mental health settings and disciplines. The study emphasizes on the burden of risk assessment and management of mental health service in order to develop decision making processes and competencies with regard to the level of risk and uncertainty. In conclusion, recording of risk assessment and management should be incorporated into the clinical record. Although risk issues require specific documentation, this should not be separated from the rest of the clinical documentation. These guidelines do not attempt to prescribe a single format for recording risk assessment and management planning. Each service should develop a format that is consistent with the clinical documentation used by the service. Documentation is more likely to be completed if there is a specific format. Mechanisms that highlight a very high level of clinical risk may be needed. Risk management plans must be clearly written, up to date, and readily accessible to any clinician involved in the management of the individual.

\subsection{Conceptual Framework}

From the various definitions of risk management and factors from different authors a conceptual model was attained. The diagram below depicts the model.

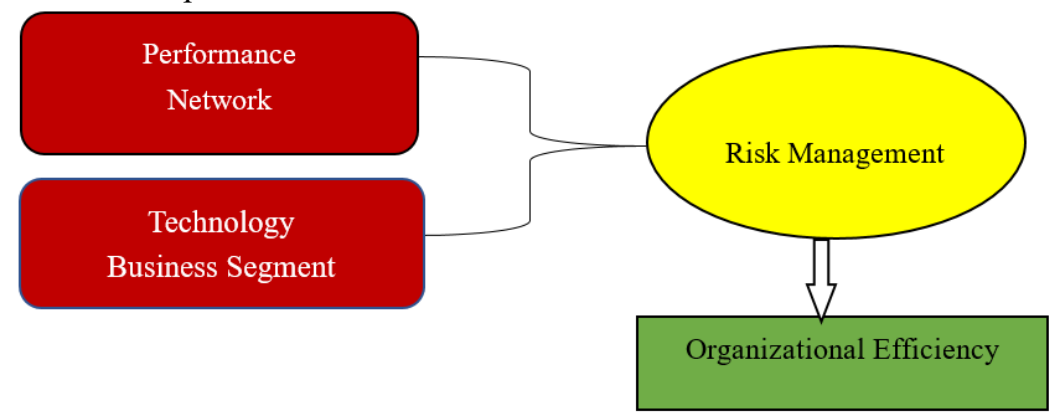

Theoretical model

Source: Researchers' Construct, 2018

\section{Methodology}

This section describes the various methods and techniques used to collect and analyze the data gathered for the study to gain a deeper understanding of the topic under study.

\subsection{Research Design}

This study was conducted using a descriptive and exploratory research design for the reason being that, descriptive research portrays an accurate profile of persons, events, or situations (Kothari, 2004). The choice of the exploratory survey research design was made based on the fact that in the study, the researcher is interested in the intention of finding out what is happening in regards to risk management towards efficiency of the study. In this study, the independent variable is the risk management which is the presumed caused of the organizational efficiency as dependent variable. The researcher designed and administered questionnaires to employees of Access Bank Ghana Ltd. The study used primary data and secondary information. Secondary information for this research was mainly through various publications culled from the internet, journals and reports prepared by various scholars in relation to the study. It has been scrutinized to assess its suitability, reliability, adequacy and accuracy. The data collection was mainly based on primary data from Access Bank Ghana Limited. It was achieved through the administering of questionnaires to the bank employees. Every questionnaire was personally handed and instructions were given to each respondent before any attempt to answer the questionnaire.

\subsection{Study Population}

A study population is the entire accessible design group of persons that is of interest to the researcher or meets the criteria the researcher is interested in studying (Daymon \& Holloway, 2011). This study targeted the employees of Access Bank Ghana Limited. 


\subsection{Sample and Sampling Technique}

Therefore, this study incorporated sampling to get a representative of the population. Simple random sampling was used to select the sample size. Out of the study population above, the sample size for the study was fifteen (15) respondents. Sample size of fifteen was selected because the number of employees responsible for risk management in most financial institutions is limited. Ten employees from the risk department and the other five were bank officials that comprise of personal bank manager, branch manager, two tellers of the bank and the customer service official.

\subsection{Data Collection Tools and Techniques}

According to Kothari (2004), research methods or techniques refers to the methods the researchers use in performing research operations to collect primary and secondary data. The primary data are those which are collected afresh and for the first time, and thus happens to be original in character (Kothari, 2004). The necessary data required for this study was primary data. The primary data was collected using a Questionnaire which consisted 14 items in 4 divisions. Division A was the demographic information on gender, age and years worked. Section B dealt with the understanding of risk management within the staff. Section $\mathrm{C}$ was the potency of risk identification, risk assessment and analysis, risk monitoring and control. Section D dealt on the influence of risk management on the organizational efficiency. The responses were measured on the 5-point Likert scale ranging from $1-5$.

\subsection{Methods of Data Analysis}

The data collected was presented by use of tables and then analyzed using descriptive statistical techniques such as, frequencies and percentages using statistical package for social sciences (SPSS version 23.0). A statistical test Ordinary Least Squares (OLS) analysis was performed to estimate the unknown variables in a linear multiple regression model. It chooses the parameters of a set of explanatory variables by minimizing the sum of the squares of the differences between independent and dependent variables. Also, Pearson Correlation test was performed to show the associations between the independent variables. It was also chosen due to the responses measured on Likert scale. The following model function was formulated:

$y=f(X+Z)$

this is therefore written in an equation form as

$y_{\text {eff }}=\alpha+b_{0} X_{R I}+b_{1} Z_{R M}+\varepsilon$.

where, $y_{\text {eff }}$ is Efficiency

$x_{R I}$ is Risk Identification factors,

$Z_{R M}$ is Risk monitoring factors,

$\alpha$ is constant (intersect)

$b_{0}$ and $b_{1}$ are coefficients of the independent variables

$\mathcal{E}$ is the error term.

\section{Results and Discussions}

4.1 Multiple regression analysis and results

Table 4-1 Multiple Regression Results

\begin{tabular}{|c|c|c|c|c|c|}
\hline \multirow{2}{*}{$\begin{array}{l}\text { Model } \\
1\end{array}$} & \multicolumn{2}{|c|}{ Unstandardized Coefficients } & \multirow{2}{*}{$\begin{array}{l}\text { Standardized Coefficients } \\
\text { Beta }\end{array}$} & \multirow[b]{2}{*}{$\mathrm{t}$} & \multirow[b]{2}{*}{$\mathrm{p}$-value } \\
\hline & $\mathrm{B}$ & Std. Error & & & \\
\hline (Constant) & -7.016 & 1.450 & & -4.837 & 0.000 \\
\hline $\mathrm{RM}$ & 0.555 & 0.163 & 0.733 & 3.398 & 0.005 \\
\hline RI & 0.229 & 0.225 & 0.220 & 1.018 & 0.329 \\
\hline
\end{tabular}

a. Dependent Variable: Efficiency

b. Predictors: Constant, Risk Monitoring, Risk Identification

Note: significantly accepted at the level of $1 \%$ and $5 \%$ respectively

Source: Researchers' Construct, 2018

From the multiple regression analysis result from the table 4-1 shows model coefficient of constant variables which was reasonable fit and there was a significantly relationship of $(\mathrm{p}<0.050)$. however only risk monitoring as an element of risk management was a positive relationship of $0.555(55.5 \%)$ and significant predictor with to organizational efficiency of $(\beta=0.733, \mathrm{t}(15)=3.398, \mathrm{p}<0.050)$. Risk identification even though it has positive relationship $0.229(22.9 \%)$ had no impact on organizational efficiency of $(\beta=0.220, t(15)=1.018, p>0.050)$. it can be suggested that the are some variables in risk identification which were not considered or the risk identification is not well considered by the management of the bank. This result can affirm to these researchers results: An efficient and effective risk management is the need of each and every organization and is one of the key responsibilities of bank. However effective risk management boosts the performance of an organization. The past 
financial crises uncovered shortcomings in the performance and risk management practices with many banks taking on excessive risk with too little regard for long run performance (Sitanta, 2011). Banks can grab opportunities with greater confidence only with an integrated approach of managing risk and performance.

\subsubsection{Analysis of Variance (ANOVA)}

The ANOVA measures the regressions model of fitness using F-statics shown from the analysis of variance in table 4-2. Hypothesis of the model fitness testing

Table 4-2 Result for The Analysis of Variance

\begin{tabular}{|l|l|l|l|l|l|}
\hline Model & Sum of Squares & df & Mean Squares & F & p-value \\
\hline Regression & 22.330 & 2 & 11.165 & 39.368 & .000 \\
Residual & 3.403 & 12 & .284 & & \\
Total & 25.733 & 14 & & & \\
\hline
\end{tabular}

a. Dependent variable: The efficiency

b. Predictors: Constant, Risk Monitoring, Risk Identification

Source: Researchers' Construct, 2018

$H_{0}$ : The fitness of the model is not appropriate the dataset.

$H_{1}$ : The fitness of the model is appropriate for the dataset.

The p-value (0.000) and the F-statistic (39.368) ascertained from the multiple regression was significant at $1 \%$ and $5 \%$ respectively. This indicates that null hypothesis can be rejected since it was not appropriate for the model dataset and accept the model for the study.

\subsection{Relationship between the Understanding of Risk, Risk Identification and Monitoring} Table4-3 Correlation Matrix Result Correlations

\begin{tabular}{|l|l|l|l|l|}
\hline \multicolumn{2}{|l|}{} & Risk Identification & Understanding of Risk & Risk Monitoring \\
\hline RI & Pearson Correlation & 1 & & \\
\hline RM & Pearson Correlation & $.857^{* *}$ & 1 & \\
\hline$* *$ Correlation is significant at the 0.01 level (2-tailed). & $.970^{* *}$ & 1 \\
\hline
\end{tabular}

Source: Researchers' Construct, 2018

Correlation matrix was performed to test the association between the risk identification, understanding of risk and risk monitoring as an element of risk management. The measuring of the association between of risk identification, understanding of risk and risk monitoring were estimated by using Pearson correlation coefficient of $(U=0.857, R M=0.874)$ and a significant value of $(U=0.000<0.001, R M=0.00<0.001)$ respectively. It shows that there is a positive strong association between them. That is any $1 \%$ change risk identification there will be a corresponding $1 \%$ strong change in the understanding and monitoring risk.

The test between understanding, identification and monitoring of risk also showed coefficient $(\mathrm{RI}=0.857$, $\mathrm{RM}=0.970)$ with a significant value of $(\mathrm{RI}=0.000<0.001, \mathrm{RM}=0.00<0.001)$. The result showed that the relationship between them is positive and $1 \%$ change in understanding of risk will have $1 \%$ change in risk identification and risk monitoring.

Lastly, the test measured between monitoring, identification and understanding of risk depicted that Pearson correlation coefficient of $(R I=0.874, \mathrm{U}=0.970)$ were positively associated at a significant value $(\mathrm{RI}=0.000<0.001$, $\mathrm{U}=0.00<0.001)$. it implies that there is a strong relationship between the various variables.

These results affirm the various definitions stated by these authors: Risk management therefore is the total process of identifying, controlling and minimizing the impact of uncertain events. Risk management refers to a process of identifying loss exposures faced by an organization and selecting the most appropriate techniques for treating these particular exposures effectively (Drennan \& Rejda, 2003). Wenk, (2005) also pointed that, risk management is the identification, assessment, and prioritization of risks followed by coordinated and economical application of resources to minimize, monitor, and control the probability and/or impact of unfortunate events or to maximize the realization of opportunities. Dorfman (2007) however holds that, ensuring that an organization makes cost effective use of risk management, first involves creating an approach built up of well-defined risk management practices and then embedding them. These risk management practices include financial risks management practices, operational risk management practices, governance risk management practices, and strategic risk management practices.

\section{Conclusion and Recommendations}

According to the findings of the study, risk management in an organization plays a vital role in the organizational efficiency and further has a positive and strong impact to it especially if all elements both considered and not are adopted. It can also be concluded that risk monitoring has the strong and positive relationship on efficiency than 
risk identification, which can imply that risk monitoring is considered much than the risk identification in Access Bank Ltd. However, the association between those three elements such as risk identification, understanding of risk and risk monitoring positively associated. The researcher can finally conclude that all elements of risk management have strong influence towards the organizational efficiency.

It can be suggested that management of Access Bank Ltd should consider all the elements and policies regarding to risk management in order to know the one that fit or has strong impact on efficiency. Also, employees are to be trained on the risk management elements and policies to achieve the organizational aim which is ultimately the efficiency.

\section{References}

Abu Hussain, H., \& Al-Ajmi, J. (2012). Risk management practices of conventional and Islamic banks in Bahrain. The Journal of Risk Finance, 13(3), 215-239.

Ahmed, A., Kayis, B., \& Amornsawadwatana, S. (2007). A review of techniques for risk management in projects. Benchmarking: An International Journal, 14(1), 22-36.

Ahmed, N., Akhtar, M. F., \& Usman, M. (2011). Risk management practices and Islamic banks: An empirical investigation from Pakistan. Interdisciplinary Journal of Research in Business, 1(6), 50-57.

Amidu, M., \& Hinson, R. (2006). Credit risk, capital structure and lending decisions of banks in Ghana. Banks and Bank systems, 1(1), 93-101.

Cooperman, E., Mills, D., \& Gardner, J. (2000). Managing Financial Institutions. An Asset/Liability Approach.

Diamond, D. W., \& Rajan, R. G. (2001). Liquidity risk, liquidity creation, and financial fragility: A theory of banking. Journal of political Economy, 109(2), 287-327.

Dorfman, M. S. (2007), "Introduction to Risk Management and Insurance”, The Chartered Insurance Institute of London.

Drennan, L., \& Rejda, G. E. (2003). Principles of Risk Management and Insurance. Risk Management, 5(3), 65 65.

Eisenhardt, K.M. (1989), "Agency theory: an assessment and review", The Academy of Management Review, Vol. 14 No.1, pp.57-74.

Emira, A., AbdelGhany, M., Elsayed, M., Elshurafa, A. M., Sedky, S., \& Salama, K. N. (2013). All-pMOS 50-V charge pumps using low-voltage capacitors. IEEE Transactions on Industrial Electronics, 60(10), 4683-4693.

Ferreira, G. (2006). AS/NZS 4360: 2004 Australian Standard for Risk Management. Jan., 2006. Recuperado em, 17.

Gyamfi, G. D. (2012). Assessing the effectiveness of credit risk management techniques of microfinance firms in Accra. Journal of Science and Technology (Ghana), 32(1), 96-103.

Halling, M., \& Hayden, E. (2006). Bank failure prediction: a two-step survival time approach, CREDIT. In Conference, Austrian National Bank, Vienna (Vol. 31, pp. 101-109).

Hassan Al-Tamimi, H. A., \& Mohammed Al-Mazrooei, F. (2007). Banks' risk management: a comparison study of UAE national and foreign banks. The Journal of Risk Finance, 8(4), 394-409.

Ishtiaq, M. (2015). Risk management in banks: determination of practices and relationship with performance.

Jensen, M.C., Meckling, W.H. (1976), "Theory of the firm: managerial behavior, agency costs and ownership structure", Journal of Financial Economics, Vol. 3 No.4, pp.305-60.

Ministry of Health, (1998). Guidelines for clinical risk assessment and management in mental health services. Issue- New Zealand.

Ross, S.A. (1973), "The economic theory of agency: the principal's problem", The American Economic Review, Vol. 63 No.2, pp.134-9.

Saleem, S., \& Abideen, Z. A. (2011). Do effective risk management affect organizational performance? European Journal of Business and Management, 3(3), 258-268.

Selma, B., Rim, M., Abdelghani, E., \& Rajhi, M. T. (2013). Risk Management Tools Practiced in Tunisian Commercial Banks. Studies in Business \& Economics, 8(1).

Shafiq, A., \& Nasr, M. (2010). Risk management practices followed by the commercial banks in Pakistan. International Review of Business Research Papers, 6(2), 308-325.

Shafique, O., Hussain, N., \& Taimoor Hassan, M. (2013). Differences in the risk management practices of Islamic versus conventional financial institutions in Pakistan: An empirical study. The Journal of Risk Finance, 14(2), 179-196.

Smith, C. W. \& Stulz, R. M. (1985), “The Determinants of Firm's Hedging Policies”, Journal of Finance and Quantitative Analysis, Vol. 20, No. 4, pp. 391-405

Tariqullah, K., \& Habib, A. (2001). Risk Management an Analysis of Issues in Islamic Financial Industry. Occasional Paper, (5).

Wanjohi, J. G. (2013). The Effect of Financial Risk Management on The Financial Performance of Commercial Banks in Kenya (Doctoral dissertation, University of Nairobi). 
Wenk, D. (2005). Risk Management and Business Continuity: Overview and Perspectives. Journal of the Chartered Insurance Institute, 3(3), 234-246.

Wood, A., \& Kellman, A. (2013). Risk management practices by Barbadian banks. International Journal of Business and Social Research, 3(5), 22-33. 